University of Nebraska - Lincoln

DigitalCommons@University of Nebraska - Lincoln

USDA National Wildlife Research Center - Staff Publications
U.S. Department of Agriculture: Animal and Plant Health Inspection Service

November 2006

\title{
Using Baits to Deliver Pharmaceuticals to Feral Swine in Southern Texas
}

Tyler A. Campbell

United States Department of Agriculture, Animal and Plant Health Inspection Service, Wildlife Services, National Wildlife Research Center, tcampbell@eastfoundation.net

Steven J. Lapidge

Invasive Animals Cooperative Research Centre, Unley, South Australia

David B. Long

United States Department of Agriculture, Animal and Plant Health Inspection Service, Wildlife Services, National Wildlife Research Center

Follow this and additional works at: https://digitalcommons.unl.edu/icwdm_usdanwrc

Part of the Environmental Sciences Commons

Campbell, Tyler A.; Lapidge, Steven J.; and Long, David B., "Using Baits to Deliver Pharmaceuticals to Feral Swine in Southern Texas" (2006). USDA National Wildlife Research Center - Staff Publications. 412.

https://digitalcommons.unl.edu/icwdm_usdanwrc/412

This Article is brought to you for free and open access by the U.S. Department of Agriculture: Animal and Plant Health Inspection Service at DigitalCommons@University of Nebraska - Lincoln. It has been accepted for inclusion in USDA National Wildlife Research Center - Staff Publications by an authorized administrator of DigitalCommons@University of Nebraska - Lincoln. 


\title{
Using Baits to Deliver Pharmaceuticals to Feral Swine in Southern Texas
}

TYLER A. CAMPBELL,' 1 United States Department of Agriculture, Animal and Plant Health Inspection Service, Wildife Services, National Wildlife Research Center, Texas Field Station, Texas A\&M University-Kingsville, Kingsville, TX 78363, USA

STEVEN J. LAPIDGE, Invasive Animals Cooperative Research Centre, Unley, South Australia 5061, Australia

DAVID B. LONG, United States Department of Agriculture, Animal and Plant Health Inspection Service, Wildlife Services, National Wildlife Research Center, Texas Field Station, Texas A\&M University-Kingsville, Kingsville, TX 78363, USA

\begin{abstract}
Few studies have evaluated oral delivery systems of pharmaceuticals (e.g., vaccines, fertility control agents, and toxicants) to feral swine (Sus scrofa) in the United States. Our objective was to assess, through a field trial, the percentage of feral swine and nontarget animals that remove and consume baits intended to transport pharmaceuticals to feral swine in southern Texas, USA. We hand-placed 1,178 iophenoxic acid (IA)-marked baits distributed over 1,721 ha (68 baits $/ \mathrm{km}^{2}$ ) in April 2005 and monitored speciesspecific bait removal and consumption using track stations, automated camera systems, and serum IA values from captured animals. Ninety percent of baits were removed after 72 hours. For baits for which we determined the species that "definitely" or "likely" removed bait using track stations and cameras, 51\% were taken by raccoons (Procyon lotor), 22\% were taken by feral swine, and $20 \%$ were taken by collared peccaries (Tayassu tajacu). We found elevated serum IA values in $74 \%$ of trapped feral swine, $89 \%$ of raccoons, and $43 \%$ of opossums (Didelphis virginiana). Our oral delivery system was successful in marking a substantial proportion of feral swine. However, our observed removal rates suggest that the majority of the baits were taken by nontarget species and, therefore, unsuitable for most pharmaceutical applications in their current form. (WILDLIFE SOCIETY BULLETIN 34(4):1184-1189; 2006)
\end{abstract}

\section{Key words}

baits, feral swine, iophenoxic acid, oral delivery system, Sus scrofa, vaccine, wild hog, wild pig.

Feral swine (Sus scrofa) are an exotic invasive species first introduced into the United States as early as the 1400s when Europeans were exploring the North American continent (Mayer and Brisbin 1991). Subsequently, many accidental (e.g., domestic stock) and intentional (e.g., Eurasian wild boar) introductions have occurred. In a recent survey of feral swine distributions, the Southeastern Cooperative Wildlife Disease Study reported feral swine occurring in 28 states stretching transcontinental from California to Virginia, USA, with isolated populations in more northern states ( $<$ http://www.uga.edu/scwds/dist_maps/swine04.html $>$ ). Current population estimates for the United States are 4 million feral swine (Nettles 1997, Pimentel et al. 2000) with $\geq 2$ million occurring in Texas alone (Mapston 2004). Feral swine continue to expand their range, in part, because of their adaptability and high reproductive potential, which is $\geq 4$ times that of native ungulates (Taylor et al. 1998). Today, feral swine are the most abundant introduced ungulate in the United States (Mayer and Brisbin 1991, Sweeney et al. 2003).

Ecologists, natural resource managers, and agricultural producers have recognized that feral swine can alter ecosystem processes. The deleterious impacts of feral swine on ecosystems are well documented (Singer et al. 1984, Lacki and Lancia 1986, Engeman et al. 2004, Seward et al. 2004); however, empirical data on potential solutions to these problems are limited. The fact that many feral swine populations across the United States are considered locally

${ }^{1}$ E-mail: tyler.a.campbell@aphis.usda.gov or regionally overabundant and continue to expand indicates that traditional control strategies often have been unsuccessful (Stevens 1996, Mapston 2004). This, coupled with the disease threats that feral swine pose to United States agriculture (van der Leek 1989, Witmer et al. 2003, Corn et al. 2004), has led researchers to identify the need for 1) developing vaccine and delivery systems for feral swine (Fletcher 1989, Wardley 1989, Kavanaugh and Linhart 2000), 2) developing fertility control and delivery systems for feral swine (Nettles 1997, Killian et al. 2003, Miller et al. 2003), and 3) developing species-specific biological controls and lethal baiting strategies (Peine and Farmer 1990, Witmer et al. 2003).

Few studies have evaluated using baits to deliver pharmaceuticals (e.g., vaccines, fertility control agents, and toxicants) to feral swine in the United States. Fletcher et al. (1990) concluded that oral vaccine delivery to feral swine was feasible, and Kavanaugh and Linhart (2000) determined baits could be used to deliver oral pharmaceuticals to feral swine. Both of these studies were conducted on Ossabaw Island, Georgia, USA, more than a decade ago. It is uncertain if their findings are applicable to mainland populations within different regions. For example, many potential nontarget species, such as opossums (Didelphis virginiana), coyotes (Canis latrans), gray foxes (Urocyon cinereoargenteus), red foxes (Vulpes vulpes), striped skunks (Mephitis mephitis), bobcats (Lynx rufus), and armadillos (Dasypus novemcinctus) were absent from Ossabaw Island (Fletcher et al. 1990, Kavanaugh and Linhart 2000). 
Additional progress in this important topic has not been made in the United States.

Our objective was to assess, through a field trial, the percentage of feral swine and nontarget animals that remove and consume baits intended to transport pharmaceuticals to feral swine in southern Texas. Given the swine-specific characteristics of the experimental baits in Australia (>90\% removal by feral swine; S. J. Lapidge, Invasive Animals Cooperative Research Centre, unpublished data), we hypothesized that the baits also would be specific to feral swine in southern Texas.

\section{Study Area}

We conducted our field trial on private property in Duval County, Texas $\left(27^{\circ} 22^{\prime} \mathrm{N}, 98^{\circ} 18^{\prime} \mathrm{W}\right)$, which was purchased in 1996 and managed for recreational uses. The 1,721-ha area occurred in the Rio Grande Plains ecoregion (Gould 1975), where precipitation averaged $67.9 \mathrm{~cm} /$ year (National Climatic Data Center, <http://www.ncdc.noaa.gov $>$ ) and elevations ranged from 50-100 m. Mean monthly high temperatures from March to April were $27.8^{\circ} \mathrm{C}$ (National Climatic Data Center, <http://www.ncdc.noaa.gov $>$ ). Soils on the area were well-drained fine sandy loams, belonging to the Runge-Delfina-Delmita soil associations (Fair 1995). Overstory vegetation was dominated by honey mesquite (Prosopis glandulosa), huisache (Acacia farnesiana), and granjeno (Acacia berlandieri). Understory vegetation was dominated by prickly pear cactus (Opuntia spp.) and bufflegrass (Cenchrus ciliaris). Numerous mammals were present on the area, including opossums, coyotes, gray foxes, raccoons (Procyon lotor), armadillos, badgers (Taxidea taxus), striped skunks, bobcats, eastern cottontail rabbits (Sylvilagus floridanus), black-tailed jackrabbits (Lepus californicus), southern plains woodrats (Neotoma micropus), hispid cotton rats (Sigmodon hispidus), collared peccaries (Tayassu tajacu), white-tailed deer (Odocoileus virginianus), and feral swine. With the exception of 10 horses enclosed in a 10-ha pasture, no domestic livestock were present.

\section{Methods}

Our trial occurred from March to April 2005 and used PIGOUT ${ }^{\circledR}$ Feral Pig Bait (Prototype 2, Animal Control Technologies Australia P/L, Somerton, Victoria, Australia). Baits were grain based with fish flavor added, cylindrical in shape, approximately $9 \times 5 \mathrm{~cm}$, and weighed $250 \mathrm{~g}$. Baits had an 8-mm hole drilled into the center, within which the serum marker iophenoxic acid (IA; Larson et al. 1981, Follmann et al. 1987, Knowlton and Olmstead 2001) was injected at $22.7 \mathrm{mg} / \mathrm{bait}$, a quantity known to mark feral swine serum (Fletcher et al. 1990).

We determined serum IA directly using high-performance liquid chromatography (HPLC; Jones 1994) and liquid chromatography-mass spectrometry (LC/MS; Wiles and Campbell 2006), rather than through indirect serum iodine methods (Henrey 1964). Consequently, it was necessary to determine baseline serum IA values of feral swine, raccoons, and opossums. We collected baseline serum samples from 25
March to 8 April on the study area and from 23 to 30 April at sites $\geq 8 \mathrm{~km}$ and $\leq 15 \mathrm{~km}$ from the study area. We captured and bled 8 feral swine, 6 raccoons, and 5 opossums for baseline serum IA determination.

On 15 April we hand-placed 1,100 IA-marked baits from 0700 to 1500 on transects $(n=30)$ oriented on a $273^{\circ}$ azimuth. We spaced transects at 260-m intervals and we dropped baits every $65 \mathrm{~m}$ along transect routes. Baits placed on 3 randomly selected transects were geo-referenced with a handheld Global Positioning System (GPS) unit (GeoXT, Trimble Navigation, Sunnyvale, California) and we raked a $2-\mathrm{m}^{2}$ area surrounding the bait to bare soil (Linhart and Knowlton 1975). From 0700 to 1200 on 18 April (72 hr with minimal disturbance on the study site), we revisited these baits and recorded presence or absence of bait, condition of bait, and tracks present in raked areas following Fletcher et al. (1990).

We monitored 78 additional baits ( 2 from 15-21 Apr, 38 from 15-18 Apr, and 38 from 18-21 Apr) with automated camera systems (Deer Cam-200; Non-typical, Park Falls, Wisconsin). With the addition of these baits, our overall bait density was 68 baits $/ \mathrm{km}^{2}$. Our camera systems used a 35-mm auto-focus camera (Trip 505; Olympus America, Denver, Colorado) with automated flash and film advance. We programmed camera systems to maintain a 30 -second delay between pictures and operated systems at "high" sensitivity. We distributed camera-monitored baits throughout the study area within $100 \mathrm{~m}$ of roads, and we positioned camera systems on native vegetation (e.g., tree limbs) or artificial structures (e.g., fence posts) at $3-5 \mathrm{~m}$ from baits. When possible, we oriented camera systems in a northern direction to minimize false triggers by solar radiation and backlighting of subjects (Kucera and Bennett 1993, Langdon 2001). Similar to above, we raked a $2-\mathrm{m}^{2}$ area surrounding the bait to bare soil. We determined speciesspecific bait contact and removal by track impressions in the soil and examination of photos. We tallied photographic data daily into 5 categories: definitely removed by species, likely removed by species, possibly removed by species, removed by unknown species, and not removed. The "definite" category included photographs in which we observed the bait in the mouth of an animal or a series of photographs $\leq 5$ minutes apart in which only the species of record was observed and the bait was removed. The "likely" category included a series of photographs $\leq 30$ minutes apart in which we observed only the species of record and the bait was removed. The "possible" category included a series of photographs $>30$ minutes apart in which we observed only the species of record and the bait was removed. We inspected camera-monitored baits daily on and following 18 April.

We prebaited 15 corral-style and 9 box-style feral swine traps with soured whole-kernel corn from 25 March to 20 April. Our approximate density of swine traps was 1.4 traps/ $\mathrm{km}^{2}$. We concurrently prebaited 20 mesomammal live traps (Model 108; Tomahawk Live Trap, Tomahawk, Wisconsin) adjacent to the aforementioned swine traps. We set and 
Table 1. Number of PIGOUT® baits removed by species as determined by photographs generated from automated camera systems $(n=78)$, 15-21 Apr 2005, Duval County, Texas, USA.

\begin{tabular}{lcccc}
\hline \multicolumn{1}{c}{ Species } & Definite $^{\mathbf{a}}$ & Likely $^{\mathbf{b}}$ & Possible $^{\mathbf{c}}$ & Total \\
\hline Raccoon & 4 & 17 & 2 & 23 \\
Feral swine & 3 & 6 & 3 & 12 \\
Collared peccary & 3 & 5 & & 8 \\
White-tailed deer & & & 6 & 6 \\
Coyote & 1 & & 1 & 2 \\
Opossum & 1 & & & 1 \\
Striped skunk & 1 & & & 1 \\
Unknown & & & & 6 \\
Not removed & 6 & & & 6 \\
\hline
\end{tabular}

${ }^{a}$ Bait observed in mouth of animal or series of photographs $\leq 5$ min apart in which only species of record was observed and bait was removed.

b Series of photographs $\leq 30$ min apart in which only species of record was observed and bait was removed.

${ }^{c}$ Series of photographs $>30$ min apart in which only species of record was observed and bait was removed.

checked feral swine and mesomammal traps from 20 April to 29 April. We checked traps daily just after sunrise to reduce heat exposure. We euthanized captured animals by gunshot (AVMA 2001), sexed, aged (Petrides 1949, Sanderson 1950, Matschke 1967), bled, and weighed them. We immediately released nontarget animals (e.g., whitetailed deer, collared peccaries, and southern plains woodrats) upon discovery. All capture and handling procedures were approved by the Institutional Animal Care and Use Committee (Permit No. QA-1283) at the National Wildlife Research Center.

We collected blood from feral swine and mesomammals obtained at capture (both baseline and trial collections) and removed serum following centrifugation. We placed serum in labeled cryogenic vials (VWR International, West Chester, Pennsylvania) and stored vials at $-20^{\circ} \mathrm{C}$. We submitted frozen serum to the Texas Veterinary Diagnostic Laboratory (College Station, Texas) to determine serum IA values using direct IA methodologies (HPLC and LC/MS, see above).

We reported descriptive statistics pertaining to speciesspecific bait removal and consumption ([no. of marked animals/no. sampled animals] $\times 100 \%)$ rates. Our capture success of opossums limited our statistical analyses; however, we captured sufficient numbers of feral swine and raccoons to conduct between-age comparisons in consumption rates using the chi-square statistic with Yates correction (Alder and Roessler 1977). We determined statistical significance at $\alpha=0.05$.

\section{Results}

We recorded presence or absence of 131 of the 1,100 baits dropped along transects. Of these, 118 (90\%) were removed after 72 hours. Of the 13 that were present, 8 had mild to moderate ant damage, 3 were partially consumed, presumably by small mammals, but otherwise in good condition, and 2 remained moist and in excellent condition. Soil
Table 2. Serum iophenoxic acid (IA) results from animals captured (2129 Apr 2005) following IA-marked PIGOUT® bait distribution on 15 Apr 2005 in Duval County, Texas, USA.

\begin{tabular}{clcc}
\hline \multirow{2}{*}{ Species } & Age category & $\begin{array}{c}\text { No. of marked/ } \\
\text { no. in sample }\end{array}$ & \% marked \\
\hline \multirow{2}{*}{ Feral swine } & Adult & $9 / 11$ & 82 \\
& Juvenile & $14 / 20$ & 70 \\
\multirow{2}{*}{ Raccoon } & Both ages & $23 / 31$ & 74 \\
& Adult & $14 / 15$ & 93 \\
& Juvenile & $3 / 4$ & 75 \\
\multirow{2}{*}{ Opossum } & Both ages & $17 / 19$ & 89 \\
& Both ages & $3 / 7$ & 43 \\
\hline
\end{tabular}

conditions prohibited definitive conclusions regarding animal tracks deposited in raked areas.

We generated 472 photographs of the 78 cameramonitored baits over $\leq 6$ nights. We recorded 98 photos of raccoons, 87 photos of collared peccaries, 69 photos of southern plains woodrats, 48 photos of white-tailed deer, 33 photos of feral swine, 15 photos of eastern cottontail rabbits, 6 photos of opossums, 4 photos of white-tipped doves (Leptotila verreauxi), 3 photos of coyotes, 3 photos of feral cats (Felis silvestris catus), 2 photos of striped skunks, 1 photo of an armadillo, 1 photo of a bobcat, and 1 photo of an unknown small mammal. Of the 41 baits removed and tallied in the "definite" or "likely" categories, we found $51 \%$ were removed by raccoons, $22 \%$ were removed by feral swine, $20 \%$ were removed by collared peccaries, $2 \%$ were removed by coyotes, $2 \%$ were removed by opossums, and $2 \%$ were removed by striped skunks (Table 1). Similar to the baits distributed along transects, we found $90 \%$ of cameramonitored baits were removed in $\leq 72$ hours.

Direct IA determination of baseline serum samples collected from all 19 individuals were $<25$ parts per billion (ppb) IA (the lowest unit of measure). Consequently, we considered animals with serum IA values $>25 \mathrm{ppb}$ to be marked through bait consumption. We captured 31 feral swine, 19 raccoons, and 7 opossums during our 9-day trapping effort. We found 23 of 31 (74\%) feral swine to have IA-marked serum (Table 2). Serum IA values of marked feral swine ranged from 53 to $2,207 \mathrm{ppb}(\bar{x}=848, \mathrm{SD}=$ 666). We found no difference $\left(\chi_{1}^{2}=0.62, P=0.45\right)$ by age in proportion of feral swine that were marked. We discovered 17 of $19(89 \%)$ raccoons to have IA-marked serum (Table 2). Serum IA values of marked raccoons ranged from 40 to $9,322 \mathrm{ppb}(\bar{x}=3,930, \mathrm{SD}=2,906)$. We did not find age differences $\left(\chi_{1}^{2}=1.19, P=0.32\right)$ in the proportion of raccoons that were marked. We found 3 of 7 (43\%) opossums to have IA-marked serum (Table 2). Serum IA values of marked opossums ranged from 43 to $711 \mathrm{ppb}(\bar{x}=$ $307, \mathrm{SD}=355$ ).

\section{Discussion}

Fletcher et al. (1990) demonstrated 95\% bait consumption by feral swine when fish meal-based baits were distributed at 488 baits $/ \mathrm{km}^{2}$ within an insular population in Georgia. In North Queensland, Australia, Mitchell (1998) found 63\% bait consumption by feral swine when bovine-based baits 
were aerially deployed at 18 baits $/ \mathrm{km}^{2}$. Furthermore, Fleming et al. (2000) discovered 31-72\% bait consumption by feral swine when kangaroo-based baits were aerially applied at $45-49$ baits $/ \mathrm{km}^{2}$ in New South Wales, Australia, with variability attributed to varying feral swine densities. Our observed consumption of $74 \%$ by feral swine was intermediate between work from Australia (lower bait density and lower bait consumption) and insular Georgia (very high bait density and higher bait consumption). However, our feral swine bait consumption was not overtly different from the maximum reported in New South Wales (applied at 45-49 baits $/ \mathrm{km}^{2}$ ), and we agree with Fleming et al. (2000) that under ideal circumstances feral swine density should be considered when comparing bait consumption. Unfortunately, reliable and cost-effective methods to survey feral swine densities do not exist for populations occurring in southern Texas (e.g., see Shupe and Beasom 1987) and further work developing these techniques is needed (Sweitzer et al. 2000, Sweeney et al. 2003). Nonetheless, our oral delivery system was successful in marking a substantial proportion of feral swine and, therefore, showed promise.

Ongoing work in Australia has found baits to be highly specific to feral swine with $>90 \%$ removal by the target species (S. J. Lapidge, Invasive Animals Cooperative Research Centre, unpublished data). This is important because these baits will be deployed broad-scale and will initially contain the compound sodium fluoroacetate (1080) to poison feral swine (O'Brien and Lukins 1988, O'Brien et al. 1988, Lapidge et al. 2004, Twigg et al. 2005). In the United States, no toxicants are currently registered for use on feral swine (Littauer 1993, Miller et al. 2003, Witmer et al. 2003), despite their demonstrated effectiveness in other localities (Hone and Pedersen 1980, Coblentz and Baber 1987, McIlroy et al. 1989, Choquenot et al. 1990). However, our observed removal rates suggest that the majority of the baits were removed by nontarget species and therefore unsuitable to deliver toxicants, anyway. A more realistic use for oral delivery systems in the United States may be to deliver fertility control agents or vaccines (Fletcher et al. 1990).

In the United States, pseudorabies virus (PRV) was successfully eradicated from domestic swine in late 2004, in part through the use of gene-deleted PRV vaccines (Mengeling et al. 1997, Zuckermann 2000). This accomplishment has important economic implications for pork producers interested in international trade. However, PRV continues to circulate in feral populations. For example, in a review of PRV serological surveys of feral swine, Müller et al. (2000) reports prevalence rates of $43-46 \%$ in Hawaii, USA, $36 \%$ in Texas, 35\% in Florida, USA, 19-22\% across several southeastern states, $7-10 \%$ in Georgia, and 3\% in California. This has led to the suggestion that feral swine are a reservoir of PRV, representing a significant risk of infecting domestic swine and native wildlife (Müller et al. 2002, Corn et al. 2004). One potential solution is to orally administer genedeleted PRV vaccines to feral swine, similar to the national oral rabies vaccination program. However, wild PRV strains (Platt et al. 1983) and gene-deleted vaccines (Weigel et al. 2003) can initiate immune responses in raccoons. This may become problematic if immunized raccoons or other wildlife (Weigel et al. 2000) carry and shed PRV, thereby increasing the risk of transmission to other wild populations or domestic herds (Weigel et al. 2003). Consequently, as with toxicant delivery systems, it would be prudent to develop a delivery system for PRV vaccines that is specific to feral swine. The baits used in our trial did not achieve this requisite, as $78 \%$ of the camera-monitored baits in the "definite" or "likely" categories were removed by nontarget animals and $89 \%$ of raccoons and $43 \%$ of opossums consumed baits.

Research on fertility-control agents in feral swine is ongoing. For example, Killian et al. (2003) found a singleshot gonadotropin-releasing hormone $(\mathrm{GnRH})$ vaccine was successful at preventing pregnancy in $90 \%$ of feral sows over a 36-week period. However, GnRH is a common hormone found in wild and domestic animals and is indirectly responsible for regulating reproductive steroid and gamete production by the testes and ovaries. Consequently, any animal that ingested baits containing the $\mathrm{GnRH}$ vaccine and subsequently produced and maintained GnRH antibodies at sufficient titers would likely have impaired reproductive capacity. This has been demonstrated in white-tailed deer (Miller et al. 2000), feral cats (Levy et al. 2004), cattle (Cook et al. 2000), sheep (Kiyma et al. 2000), and horses (Malmgren et al. 2001). Again, our delivery system was not specific to feral pigs and, therefore, was not a suitable candidate to deliver a $\mathrm{GnRH}$ vaccine in its current form.

Our baiting system was successful at minimizing bait damage caused by fire ants (Solenopsis wagneri). Previous work in southern Texas on dog-food-based baits intended for coyotes distributed in July found $43-50 \%$ of baits remaining after 24 hours and $68-89 \%$ of baits remaining after 48 hours to have fire ant damage, whereas fire ants were absent from baits distributed in January (Farry et al. 1998). We observed $62 \%$ of the baits that remained after 72 hours to have mild to moderate fire ant damage. However, we did not observe fire ants constructing mounds over baits, thereby rendering them inaccessible (e.g., see Fletcher et al. 1990, Farry et al. 1998). We attribute our comparatively minor ant damage to the cooler temperatures during April, the general lack of precipitation in the months preceding our trial, and coarser soil textures on our study site.

Our observed bait consumption by feral swine is encouraging. However, the non-species-specific characteristics of the bait suggest that our baiting system, in its current form, is not suitable for management applications in southern Texas. It is uncertain whether nontarget bait consumption would be as high in a habitat with a more open woody vegetation canopy and lower mesomammal density, as compared to the principally closed-canopy habitat present at the study site. We concur with Fletcher et al. (1990) that more research is needed into understanding the dynamics of nontarget animal use of baits. For example, Kavanaugh and 
Linhart (2000) used generic grain-based baits with an overcoat of different odor attractants in an effort to target specific species. Even though Kavanaugh and Linhart (2000) were unable to identify species-specific attractants, we believe that this approach has merit and warrants further investigation.

\section{Acknowledgments}

Financial support was provided by the United States Department of Agriculture, Animal and Plant Health Inspection Service, Wildlife Services, National Wildlife

\section{Literature Cited}

Alder, H. L., and E. B. Roessler. 1977. Introduction to probability and statistics. Sixth edition. Freeman, San Francisco, California, USA.

American Veterinary Medical Association [AVMA]. 2001. 2000 report of the AVMA panel on euthanasia. Journal of the American Veterinary Medical Association 218:669-696.

Choquenot, D., B. Kay, and B. Lukins. 1990. An evaluation of warfarin for the control of feral pigs. Journal of Wildlife Management 54:353359 .

Coblentz, B. E., and D. W. Baber. 1987. Biology and control of feral pigs on Isla Santiago, Galapagos, Ecuador. Journal of Applied Ecology 24:403-418.

Cook, R. B., J. D. Popp, J. P. Kastelic, S. Robbins, and R. Harland. 2000. The effects of active immunization against $\mathrm{GnRH}$ on testicular development, feedlot performance, and carcass characteristics of beef bull. Journal of Animal Science 78:2778-2783.

Corn, J. L., D. E. Stallknecht, N. M. Mechlin, M. P. Luttrell, and J. R. Fischer. 2004. Persistence of pseudorabies virus in feral swine populations. Journal of Wildlife Diseases 40:307-310.

Engeman, R. M., H. T. Smith, R. Severson, M. A. Severson, S. A. Shwiff, B. Constantin, and D. Griffin. 2004. The amount and economic cost of feral swine damage to the last remnant of a basin marsh system in Florida. Journal for Nature Conservation 12:143147.

Fair, W. S. 1995. Habitat requirements and capture techniques of Texas horned lizards in South Texas. Thesis, Texas A\&M UniversityKingsville, Kingsville, USA.

Farry, S. C., S. E. Henke, S. L. Beasom, and M. G. Fearneyhough. 1998. Efficacy of bait distributional patterns to deliver canine rabies vaccines to coyotes in southern Texas. Journal of Wildlife Diseases 34:23-32.

Fleming, P. J. S., D. Choquenot, and R. J. Mason. 2000. Aerial baiting of feral pigs (Sus scrofa) for the control of exotic disease in the semiarid rangelands of New South Wales. Wildlife Research 27:531-537.

Fletcher, W. O. 1989. Oral baits capable of delivering vaccines to wild swine. Page 57 in Proceedings of the feral pig symposium. Livestock Conservation Institute, Madison, Wisconsin, USA.

Fletcher, W. O., T. E. Creekmore, M. S. Smith, and V. F. Nettles. 1990. A field trial to determine the feasibility of delivering oral vaccines to wild swine. Journal of Wildlife Diseases 26:502-510.

Follmann, E. H., P. J. Savarie, D. G. Ritter, and G. M. Baer. 1987. Plasma marking of arctic foxes with iophenoxic acid. Journal of Wildlife Diseases 23:709-712.

Gould, F. W. 1975. Texas plants-a checklist and ecological summary. Texas Agricultural Experiment Station, Texas A\&M University, College Station, USA.

Henrey, R. J. 1964. Clinical chemistry: principles and techniques. Harper and Row, New York, New York, USA

Hone, J., and H. Pedersen. 1980. Changes in a feral pig population after poisoning. Proceedings of the Vertebrate Pest Conference 9: 176-182.

Jones, A. 1994. High-performance liquid chromatographic determination of iophenoxic acid in serum. Journal of Chromatography B: Biomedical Applications 654:293-296.

Kavanaugh, D. M., and S. B. Linhart. 2000. A modified bait for oral
Research Center. We thank D. Pedrotti and M. Cisneros for providing locations to conduct research. We appreciate the assistance of R. Carmichael, J. Hinojosa, G. Hood, R. Kaiser, J. Kersh, R. Mancinas, K. Porter, L. Robertson, and A. Tjelmeland in distributing baits. We are grateful to $\mathrm{S}$. Henke for providing miscellaneous equipment. Earlier versions of this manuscript were improved through comments of R. McLean, C. Wyckoff, and M. Reidy. Our mention of commercial products herein is for identification purposes and does not constitute endorsement or censure by the United States Department of Agriculture.

delivery of biological agents to raccoons and feral swine. Journal of Wildlife Diseases 36:86-91.

Killian, G., L. Miller, J. Rhyan, T. Dees, D. Perry, and H. Doten. 2003. Evaluation of $\mathrm{GnRH}$ contraceptive vaccine in captive feral swine in Florida. Proceedings of the Wildlife Damage Management Conference 10:128-133.

Kiyma, Z., T. E. Adams, B. W. Hess, M. L. Riley, W. J. Murdoch, and G. E. Moss. 2000. Gonadal function, sexual behavior, feedlot performance, and carcass traits of ram lambs actively immunized against $\mathrm{GnRH}$. Journal of Animal Science 78:2237-2243.

Knowlton, F. F., and S. R. Olmstead. 2001. Using iophenoxic acid injections of prey to identify mammals that feed on them. Wildlife Society Bulletin 29:495-500.

Kucera, T. E., and R. H. Bennett. 1993. The Trailmaster ${ }^{\circledR}$ camera system for detecting wildlife. Wildlife Society Bulletin 21:505-508.

Lacki, M. J., and R. A. Lancia. 1986. Effects of wild pigs on beech growth in Great Smoky Mountains National Park. Journal of Wildlife Management 50:655-659.

Langdon, C. A. 2001. A comparison of white-tailed deer population estimation methods in West Virginia. Thesis, West Virginia University, Morgantown, USA.

Lapidge, S. J., B. Cowled, and M. Smith. 2004. Ecology, genetics and socio-biology: practical tools in the design of target-specific feral pig baits and baiting procedures. Proceedings of the Vertebrate Pest Conference 21:317-322.

Larson, G. E., P. J. Savarie, and I. Okuno. 1981. Iophenoxic acid and mirex for marking wild, bait consuming animals. Journal of Wildlife Management 45:1073-1077.

Levy, J. K., L. A. Miller, P. C. Crawford, J. W. Ritchey, M. K. Ross, and K. A. Fagerstone. 2004. GnRH immunocontraception of male cats. Theriogenology 62:1116-1130.

Linhart, S. B., and F. F. Knowlton. 1975. Determining the relative abundance of coyotes by scent station lines. Wildlife Society Bulletin 3:119-124.

Littauer, G. A. 1993. Control techniques for feral hogs. Pages 139-148 in C. W. Hanselka and J. F. Cadenhead, editors. Feral swine: a compendium for resource managers: proceedings of a conference. Texas Agricultural Extension Service, College Station, USA.

Malmgren, L., O. Andresen, and A. M. Dalin. 2001. Effect of GnRH immunization on hormonal levels, sexual behavior, semen quality and testicular morphology in mature stallions. Equine Veterinary Journal 33:75-83

Mapston, M. E. 2004. Feral hogs in Texas. Texas Cooperative Extension Service B-6149, Texas A\&M University, College Station, USA.

Matschke, G. H. 1967. Aging European wild hogs by dentition. Journal of Wildlife Management 31:109-113.

Mayer, J. J., and I. L. Brisbin Jr. 1991. Wild pigs of the United States: their history, comparative morphology, and current status. University of Georgia, Athens, USA.

Mcllroy, J. C., M. Braysher, and G. R. Saunders. 1989. The effectiveness of a warfarin poisoning campaign against feral pigs, Sus scrofa, in Namadgi National Park. Australian Wildlife Research 16:195-202.

Mengeling, W. L., S. L. Brockmeier, K. M. Lager, and A. C. Vorwald. 
1997. The role of biotechnologically engineered vaccines and diagnostics in pseudorabies (Aujeszky's disease) eradication strategies. Veterinary Microbiology 55:49-60.

Miller, L. A., B. E. Johns, and G. J. Killian. 2000. Immunocontraception of white-tailed deer with $\mathrm{GnRH}$ vaccine. American Journal of Reproductive Immunology 44:266-274.

Miller, L. A., J. C. Rhyan, and G. J. Killian. 2003. Evaluation of GnRH contraceptive vaccine using domestic swine as a model for feral hogs. Proceedings of the Wildlife Damage Management Conference 10:120-127.

Mitchell, J. 1998. The effectiveness of aerial baiting for control of feral pigs (Sus scrofa) in North Queensland. Wildlife Research 25:297303.

Müller, T., F. J. Conraths, and E. C. Hahn. 2000. Pseudorabies virus infection (Aujeszky's disease) in wild swine. Infectious Disease Review 2:27-34.

Nettles, V. F. 1997. Feral swine: where we've been, where we're going. Pages 1.1-1.9 in K. L. Schmitz, editor. Proceedings of the national feral swine symposium. U.S. Department of Agriculture, Animal and Plant Health Inspection Service, Riverdale, Maryland, USA.

O'Brien, P. H., and B. S. Lukins. 1988. Factors influencing the intake of sodium monofluoroacetate (compound 1080 ) by free-ranging feral pigs. Australian Wildlife Research 15:285-291.

O'Brien, P. H., B. S. Lukins, and J. A. Beck. 1988. Bait type influences the toxicity of sodium monofluoroacetate (compound 1080) to feral pigs. Australian Wildlife Research 15:451-547.

Peine, J. D., and J. A. Farmer. 1990. Wild hog management program at Great Smoky Mountains National Park. Proceedings of the Vertebrate Pest Conference 14:221-227.

Petrides, G. A. 1949. Sex and age determination of the opossum. Journal of Mammalogy 30:364-378.

Pimentel, D., L. Lach, R. Zuniga, and D. Morrison. 2000. Environmental and economic costs of nonindigenous species in the United States. BioScience 50:53-65

Platt, K. B., D. L. Graham, and R. A. Faaborg. 1983. Pseudorabies: experimental studies in raccoons with different virus strains. Journal of Wildlife Diseases 19:297-301.

Sanderson, G. C. 1950. Methods of measuring productivity in raccoons. Journal of Wildlife Management 14:389-402.

Seward, N. W., K. C. VerCauteren, G. W. Witmer, and R. M. Engeman. 2004. Feral swine impacts on agriculture and the environment. Sheep and Goat Research Journal 19:34-40.

Shupe, T. E., and S. L. Beasom. 1987. Speed and altitude influences on helicopter surveys of mammals in brushland. Wildlife Society Bulletin 15:552-555

Singer, F. J., W. T. Swank, and E. E. C. Clebsch. 1984. Effects of wild pig rooting in a deciduous forest. Journal of Wildlife Management 48: 464-473.

Stevens, R. L. 1996. The feral hog in Oklahoma. Samuel Roberts Noble Foundation, Ardmore, Oklahoma, USA.

Sweeney, J. R., J. M. Sweeney, and S. W. Sweeney. 2003. Feral hog. Sus scrofa. Pages 1164-1179 in G. A. Feldhamer, B. C. Thompson, and J. A. Chapman, editors. Wild mammals of North America: biology, management, and conservation. Second edition. Johns Hopkins University, Baltimore, Maryland, USA.

Sweitzer, R. A., D. Van Vuren, I. A. Gardner, W. M. Boyce, and J. D. Waithman. 2000. Estimating sizes of wild pig populations in the north and central coast regions of California. Journal of Wildlife Management 64:531-543.

Taylor, R. B., E. C. Hellgren, T. M. Gabor, and L. M. Ilse. 1998. Reproduction of feral pigs in southern Texas. Journal of Mammalogy 79:1325-1331.

Twigg, L. E., T. Lowe, G. Martin, and M. Everett. 2005. Feral pigs in north-western Australia: basic biology, bait consumption, and the efficacy of 1080 baits. Wildlife Research 32:281-296.

van der Leek, M. L. 1989. Wild swine: resource or risk? Pages 11-15 in Proceedings of the feral pig symposium. Livestock Conservation Institute, Madison, Wisconsin, USA

Wardley, R. C. 1989. Vaccination of feral populations. Pages 58-62 in Proceedings of the feral pig symposium. Livestock Conservation Institute, Madison, Wisconsin, USA.

Weigel, R. M., E. C. Hahn, B. Paszkiet, and G. Scherba. 2000. Aujeszky's disease virus (ADV) in mammalian wildlife populations on swine farms in Illinois: potential for transmission to non-infected herds. Veterinary Research 31:148-149.

Weigel, R. M., E. C. Hahn, and G. Scherba. 2003. Survival and immunization of raccoons after exposure to pseudorabies (Aujeszky's disease) virus gene-deleted vaccines. Veterinary Microbiology 92:1924.

Wiles, M. C., and T. A. Campbell. 2006. Liquid chromatographyelectrospray ionization mass spectrometry for direct identification and quantification of iophenoxic acid in serum. Journal of Chromatography B 832:144-157.

Witmer, G. W., R. B. Sanders, and A. C. Taft. 2003. Feral swine-are they a disease threat to livestock in the United States? Proceedings of the Wildlife Damage Management Conference 10:316-325.

Zuckermann, F. A. 2000. Aujeszky's disease virus: opportunities and challenges. Veterinary Research 31:121-131.

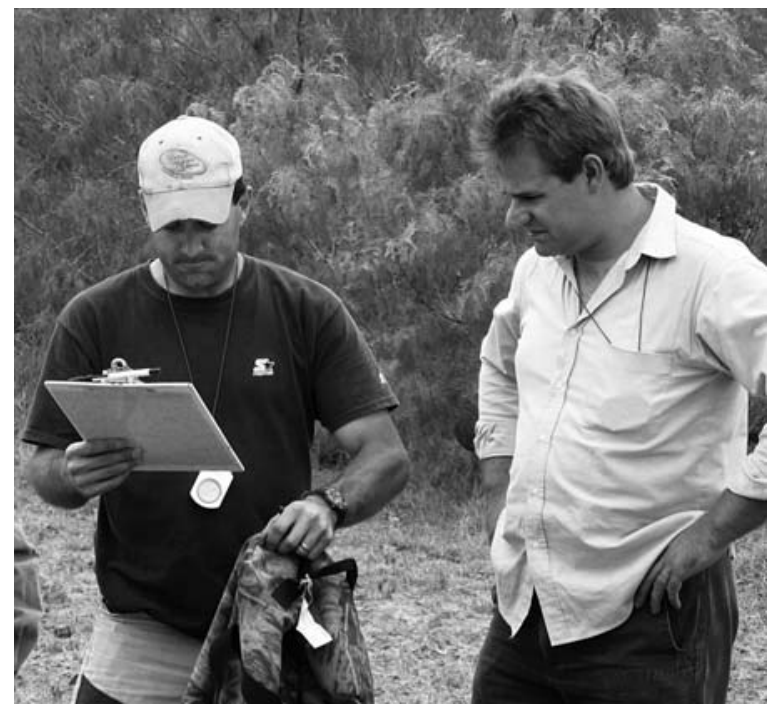

Tyler A. Campbell (left) is a research wildlife biologist at the National Wildlife Research Center (NWRC)-Texas Field Station with emphasis on feral swine management. His research interests include mammalian ecology and management. Steven $\boldsymbol{J}$. Lapidge (right) is the program manager for integrated pest management at the Pest Animal Control Cooperative Research Centre in Canberra ACT, Australia. His research interests include invasive species ecology and management. David B. Long (not pictured) is a biological technician at the NWRC-Texas Field Station. He conducts studies involving the ecology and management of feral swine and other wildlife, livestock, and human disease hosts.

Associate Editor: Pitt. 